\title{
THE COMPOSITION AND DETERMINANTS OF RURAL NON-FARM INCOME DIVERSIFICATION IN NIGERIA
}

\author{
Oluseyi Olutoyin Olugbire ${ }^{\mathrm{\varpi}}$, Oluwatosin Esther Obafunsho ${ }^{1}$, \\ Titilope Omolara Olarewaju ${ }^{1}$, Ruth Ibukun Kolade ${ }^{1}$, \\ Festus Abiodun Odediran ${ }^{1}$, Lucy Adeteju Orumwense ${ }^{1}$ \\ ${ }^{1}$ Forestry Research Institute of Nigeria, Nigeria
}

\begin{abstract}
Farming has been considered the main source of income for rural households in Nigeria, despite their involvement in other income-generating activities. Focusing on income derivable from farming alone may be partially responsible for the ineffective poverty reduction strategies in Nigeria. Using the National Living Standard Survey data collected by the National Bureau of Statistics, this paper investigated the composition and determinants of non-farm incomes of rural households in Nigeria. The results show that the share of farm, non-farm wage (NFW) and self-employment (NFS) incomes in total household incomes were $24.3 \%, 43.0 \%$ and $23.7 \%$ respectively. Households whose heads are males or have formal education had an increased likelihood of households' participation in NFW activities by $6.2 \%$ and $10.9 \%$ points respectively, while larger household size decreased it by $0.6 \%$ point. Furthermore, possession of capital assets, being a male household head and age increased the likelihood of participation in NFS employment activities by $33.3 \%, 1.5 \%$ and $0.3 \%$; while larger farm size and household size decreased it by $1.6 \%$ and $0.1 \%$ respectively. The study concludes that any policy targeting poverty reduction should focus on providing a favourable environment for poor households to access non-farm activities in the studied area.
\end{abstract}

Keywords: non-farm income, wage employment, self-employment, Tobit regression, rural Nigeria

\section{INTRODUCTION}

The poverty level in Nigeria's rural areas is remarkably high as over $80 \%$ of the population is considered to be smallholders, with more than $70 \%$ of them living in extreme poverty (FAO, 2018; Olowa, 2012; NBS, 2010). The World Bank further confirmed that extreme poverty is becoming more concentrated in rural settlements of Africa, including Nigeria and predominantly affecting the farming sector (World Bank, 2018).

The evidence from the literature shows that the share of agricultural sector in Nigeria's gross domestic product (GDP) has declined from 56\% in 1960-1964 to about $35 \%$ in 2008 (NBS, 2004; FAO, 2013), with further decline to $21 \%$ in 2018 (FAO, 2018). The reasons for this decline are obvious: for many rural households in Nigeria, agriculture is the main activity (NBS, 2004; Odoh et al., 2019) and Nigeria's farmers face many challenges that constrain their agricultural productivity and incomes. Such problems include a significant reliance on rainfed agriculture, lack of access to modern equipment, technology and agricultural extension services in the form of knowledge and information transfer. High expenses for agricultural inputs, estimated at almost $20 \%$ of the value of production, hinder productivity even further (FAO, 2018). Furthermore, only 7\% of Nigeria's

$\bowtie$ Oluseyi Olutoyin Olugbire, Department of Forest Economics and Extension Services, Forestry Research Institute of Nigeria, Jericho Hill, Ibadan, P.M.B. 5054, Oyo State, Nigeria, e-mail: olugbireolutoyin@gmail.com, https://orcid.org/0000-0002-1922-6961 
smallholders have access to credit, and the low level of infrastructural development in the rural areas hinders them from participating in local or other markets, or travelling the distance from their farm to urban centres where they could sell their products at higher prices. Despite the importance of agriculture to the rural economy, the sector's productivity limitations predispose the rural farmers to income and poverty challenges.

Several potential exit paths out of rural poverty have been suggested in the literature (Odoh et al., 2019; Williams, 2016; Davis et al., 2017; De Janvry and Sadoulet, 2000; World Bank, 1997; 2001). A common approach included an integrated rural development that focused mainly on increased productivity in agriculture (Estruch and Grandelis, 2013). Agriculture has therefore been indicated as the central element of poverty reduction strategies and any attempts to increase the productivity of agriculture and alleviate rural poverty in most developed countries have dealt with the structural sectoral problems. However, studies have shown that agriculture alone cannot reduce the high level of poverty (Byerlee et al., 2010; Pham, 2007; Schwarze, 2004); and after many decades of focusing on agriculture as the core of rural development policies, it is now clear that agriculture alone is not enough for sustainable increases in rural income (FAO, 2017; World Bank, 1997; Schwarze, 2004; De Janvry et al., 2005), hence it is imperative that rural farm households be engaged in diversified income-generating activities to improve their livelihood. The involvement of rural farm households in non-farm activities according to De Janvry et al., (2005) exhibits a higher potential for reducing rural unemployment as well as increasing household income. In many instances, expansion in rural non-farm employment is strongly linked to expansion in the agricultural sector because the agricultural sector remains the largest supplier of intermediate production inputs to other economic sectors (Lanjouw, 1998; Anderson and Leiserson, 1980).

Despite the importance of non-farm income to rural households' income, the non-farm income is still regarded as residual in national rural income reports (Illiya, 1999) which implies that non-farm sources of income might have been underestimated.

In their study, NISER (2004) examined the structure of income among rural households in Nigeria; they found that the non-farm income, as a proportion of total income of the rural majority was about $34.16 \%$, implying that non-farm income sources cannot be regarded as "residual".

A more recent study by Odoh et al. (2019) shows that over $82 \%$ of the surveyed households in south-eastern Nigeria diversified into non-farm income-generating activities, while only $17 \%$ were engaged solely in farm activities. Based on minimal estimates, Anderson and Leiserson (1980) indicated that the percentage of rural labour force engaged in non-farm work in most of the developing countries falls between $20-30 \%$. Reardon et al. (2001) also noted that about $40 \%$ of rural household incomes are from non-farm sources which is important to keep in mind in the analysis of rural livelihood strategies and in the design of rural development strategies.

This study is stimulated by this preliminary insight that rural households do not depend on farming as the only source of income, but on a variety of non-farm income sources. The nature of these incomes and the factors influencing households' decision to participate in these activities need to be better understood for priority setting. Given that the goal of any poverty reduction strategy is to increase income and other welfare indicators of rural households (Gordon and Craig, 2004), any policy which aims to increase income should first understand the composition and determinants of these income sources so that target interventions can be applied appropriately.

While the share of non-farm income in total household income has been reported in the literature (Odoh et al., 2019; Williams, 2016; NISER, 2004; Awoyemi, 2004; De Janvry and Sadoulet, 2000; Illiya, 1999), there appears to be scant empirical studies, especially at the national level in Nigeria, showing the relationship between non-farm income diversification and some household assets, hence more evidence is needed to understand what factors influence households' participation in non-farm income-generating activities and to identify appropriate policy responses. Therefore, the intent of this study was to identify the socio-economic factors which determine the decision of rural households to participate in non-farm activities. The obtained results will help in drawing policy conclusions with respect to the rural poverty reduction and rural development.

\section{METHODOLOGY}

\section{Data Source and Scope}

The data used for the study were collected by the National Bureau of Statistics (NBS). They were based on 

minants of rural non-farm income diversification in Nigeria. J. Agribus. Rural Dev., 3(57), 279-288. http://dx.doi.org/10.17306/J. JARD.2020.01344

the Nigeria Living Standards Surveys (NLSS) of households. The first round was carried out between September 2003 and August 2004, while the second round was carried out between 2009 and 2010. The questionnaire development was a joint effort of the Nigerian Bureau of Statistics, the World Bank and the National Planning Commission. The survey covered the rural areas in 36 states of the Federation and the Federal Capital Territory. Ten enumeration areas were studied in each of the states, while five were covered in Abuja. In-depth data were collected on key elements which include demographic characteristics, educational skills and training, employment and time use, social capital, agriculture, income, consumption expenditure and non-farm enterprises. The analysis focused on rural households, i.e. 14,512 in total. However, some households did not report any income and this reduced the sample size to 13,033 . The following household incomes were identified based on their sources: income earned from cropping and livestock activities; income earned from self-employment in non-farm activities such as industry, transport, construction and services; income earned from formal or informal wage, including salary, allowance, bonus, and other kinds of remuneration, and other non-productive incomes, such as remittances, transfers, rents and financial income. Non-farm activities were further categorised into self-employment and wage employment.

\section{Analytical techniques}

The study employed descriptive and econometric tools to analyse the data. Descriptive statistics such as tables and percentages were used in describing the households' income activities. Based on available data from the Living Standards Survey, agricultural activities are divided into crops and livestock activities while non-farm activities are categorised into self-employment and wageemployment activities. Econometric tools include the Tobit regression model.

\section{Measurement of poverty}

Poverty is multidimensional and no single indicator can capture all the aspects of poverty. In this study, the poor are defined as those who subsist below the poverty line. The national poverty was interpreted as the monetary value of the food and non-food expenditures needed for an individual to achieve a basic level of welfare (NBS, 2010). In calculating poverty line for 2003-04, the threshold which was considered to represent a poor household was NGN 28,836.70 per person per year, while 2009-10 poverty line was defined at NGN 55,235.20 per person per year. Those with per capita expenditures that are less than two-thirds of the poverty line are considered to be poor, while those above are non-poor.

In this study, poverty groups were computed as the terciles of the poverty index.

\section{Measurement of Income Diversification: Simpson Index of Diversity}

The index captures both the number of income sources and their relative importance, or evenness of these sources (Minot et al., 2006). It is expressed by the following formula:

where:

$$
d=1-\sum_{i}^{n} p_{i}^{2}
$$

$d$ - income diversification

$i$ - number of income sources indexed by $i$

$p_{i}-$ proportion of income generated from income source $i$.

This measure of income diversification $(d)$ illustrates the diversity of income sources in numerical terms and is bounded between the values of zero and one. The index is created by calculating each source of income weighted by its contribution to the total income.

\section{Econometric model: Tobit model}

Depending on the research questions and quality of data, the models and estimation methods may take different forms. It may, for example, be a question of household choice or probability of engaging in certain activity. The research questions addressed in this study focused on, among other things, the proportions and levels of income from different sources, and the respective determinants. The observations for both could be considered censored since both are given the value zero but not negative values. The determinants are therefore analysed using the Tobit model. The share of income from a particular income activity as well as the Simpson index of diversity was used as the dependent variables measuring participation in non-farm activities. Since these dependent variables are bounded between 0 and 1, (i.e. the variables are censored at 0.0 and 1.0). Conventional regression methods fail to take into account the qualitative difference between zero and continuous observations (Schwarze, 2004). Therefore, Tobit model, which has been originally developed for censored data, was applied for the analysis. 

minants of rural non-farm income diversification in Nigeria. J. Agribus. Rural Dev., 3(57), 279-288. http://dx.doi.org/10.17306/J. JARD.2020.01344

\section{Estimation strategy}

According to Maddala (1987), the Tobit model can be expressed as:

$$
\begin{gathered}
Y^{*}=\beta X_{i}+\mu_{i} \\
Y_{i}^{*}=\max \left(0, Y_{i}^{*}\right)
\end{gathered}
$$

where:

$$
\begin{aligned}
& Y_{i}-\text { observed censored variable } \\
& Y_{i}^{*}-\text { unobserved latent variable } \\
& \beta-\text { vector of respective parameters } \\
& X_{i} \quad \text { - vector of explanatory variables } \\
& \mu_{i}-\text { error term which is assumed to be independent- } \\
& \quad \text { ly and normally distributed with zero mean and } \\
& \quad \text { constant variance } \sigma \\
& i-1,2, \ldots, n \text { ( } n \text { is the number of observations). }
\end{aligned}
$$

The coefficients were estimated by the maximum likelihood estimation method, where the likelihood consists of the product of expressions for the probability of obtaining each observation. The explanatory variables and measurements are given below:

$X_{1}$ - land size: total area of farmland cultivated by households (ha)

$X_{2}$ - livestock: livestock units owned by households (number of heads of animals)

$X_{3}$ - assets: total value of other household disposable assets (NGN)

$X_{4}$ - hh size: household size

$X_{5}$ - age: age of the household head (years)

$X_{6}-$ sex: gender of the household head, defined as 1 $=$ male, $0=$ otherwise

$X_{7}$ - educ: education level of the household head, defined as $1=$ formal education, $0=$ otherwise

$X_{8}$ - temploy: total number of people employed in the household

$X_{9}=$ deptratio: dependency ratio, calculated as the ratio of the number of dependents to the number of independents in the household

$X_{10}$ - illness: indicator of the health status of the household head, defined as $1=$ the household head is suffering from any illness or injury, $0=$ otherwise

$X_{11}$ - socialcap: indicator of household's participation in social activities varying from zero to five $(0=$ no participation, $5=$ very active participation). A household-participation variable was created as a proxy for social capital to illustrate the rate of participation in the community activities and group memberships in the studied area
$X_{12}-$ credit: access to credit facilities, defined as $1=$ yes, $0=$ otherwise

$X_{13}$ - distance_t_wk: distance to work $(\mathrm{km})$

$X_{14}$ - migrant: migrant status, defined as $1=$ migrant, $0=$ otherwise

$X_{15}$ - region: this is defined as a dummy variable

\begin{tabular}{|c|c|c|}
\hline Variable & Mean & $\begin{array}{l}\text { Standard } \\
\text { deviation }\end{array}$ \\
\hline Landsize & 1.1655 & 1.0042 \\
\hline Livestock units owned & 4.4443 & 2.6122 \\
\hline Value of other assets & 54119 & 2647233 \\
\hline Household size & 5.6567 & 3.3153 \\
\hline Age & 46.3443 & 17.1589 \\
\hline Sex & 0.7807 & 0.4137 \\
\hline Education & 0.5699 & 0.4695 \\
\hline No of people employed & 3.1965 & 17.3586 \\
\hline Dependency ratio & 0.8906 & 0.3514 \\
\hline Membership of social Institution & 3.4319 & 1.0711 \\
\hline Access to credit & 0.4401 & 0.4964 \\
\hline Distance to work & 4.0492 & 12.2315 \\
\hline Migrant status & 0.3605 & 0.4463 \\
\hline Region & 0.3047 & 0.4603 \\
\hline $\begin{array}{l}\text { Mean annual total income } \\
\text { (Naira) }\end{array}$ & \multicolumn{2}{|c|}{191495} \\
\hline $\begin{array}{l}\text { Mean annual farm income } \\
\text { (Naira) }\end{array}$ & \multicolumn{2}{|c|}{51145} \\
\hline $\begin{array}{l}\text { Mean annual non-farm income } \\
\text { (Naira) }\end{array}$ & \multicolumn{2}{|c|}{140350} \\
\hline
\end{tabular}
representing each of the six geopolitical zones in the country: South East, South South, South West, North Central, North East and North West.

\section{RESULTS AND DISCUSSIONS}

\section{Household descriptive statistics}

Descriptive statistics of the research sample are presented in Table 1. The average age of a rural farmer in the studied area was 46 years, implying that most of

Table 1. Descriptive statistics of the variables

Source: own calculations from Nigerian Living Standards Survey. 

minants of rural non-farm income diversification in Nigeria. J. Agribus. Rural Dev., 3(57), 279-288. http://dx.doi.org/10.17306/J. JARD.2020.01344

them are still in their active productive age. The average household size was about 6 persons, while about $89 \%$ of them have people depending on them. About $78 \%$ of the households were headed by men. The average level of education was about 5 years of primary level of education. The average size of land for farming was about 1.2 hectares, implying that most of respondents are smallholders. Even fewer households had access to formal or informal credit, and the distance to the nearest market place was quite far on average. The total annual household income was about NGN 191,000. Farming accounted for less than one-third of this total; the rest was represented by non-farm income.

\section{Composition of household income by activity}

Results presented in Table 2 show that agriculture is the predominant activity among rural dwellers in the studied area; about $78 \%$ of the surveyed households are involved in this activity. The proportion of income generated from this activity by the rural households was small $(24.3 \%)$.

When non-farm activities were categorised into non-farm wage- and self-employment activities, it was shown that 15.2 and $19.7 \%$ of the households were engaged in non-farm wage- and self-employment activities. The share of income from non-farm wage employment was $43.0 \%$, while non-farm self-employment income share was $23.7 \%$. This result shows that even though the percentage of households engaged in nonfarm wage employment was lower than other activities in the studied area, in terms of returns it was the most remunerative activity in the studied area.

Table 2. Composition of household income by activity

\begin{tabular}{lccc}
\hline Income activity & $\begin{array}{c}\text { Share in total } \\
\text { income (\%) }\end{array}$ & $\begin{array}{c}\text { No of households } \\
\text { participating }\end{array}$ & $\begin{array}{c}\text { \% of } \\
\text { households }\end{array}$ \\
\hline Farm activity & 24.3 & 10212 & 78.4 \\
$\begin{array}{l}\text { Nonfarm wage } \\
\text { employment }\end{array}$ & 43.0 & 1975 & 15.2 \\
$\begin{array}{l}\text { Nonfarm self } \\
\text { employment }\end{array}$ & 23.7 & 2568 & 19.7 \\
$\begin{array}{l}\text { Other } \\
\text { Remittances }\end{array}$ & 5.9 & 1451 & 11.1 \\
\multicolumn{1}{c}{ Transfers } & 3.0 & 3800 & 29.1 \\
\hline
\end{tabular}

Source: own calculations from Nigerian Living Standards Survey.

\section{Composition of household income by poverty group}

Results presented in Table 3 show that although the mean income for the poor households was the smallest, their proportion of income from farm activities was the highest of the three expenditure categories. In terms of participation, the participation in agricultural activities was comparatively low for households that are better off (74.3\%), whereas it was the other way round for non-farm activities. $19.2 \%$ of the richer households participated in non-farm wage employment while $22.7 \%$ of the same households participated in non-farm self-employment activities. Only $9.6 \%$ of the poorest households were engaged in non-farm wage-employment activities and $17.7 \%$ participated in non-farm self-employment activities.

Table 3. Composition of household income by poverty group

\begin{tabular}{|c|c|c|c|}
\hline Expenditure tercile & First & Second & Third \\
\hline \multicolumn{4}{|c|}{ Farm income } \\
\hline Shares in total income (\%) & 25.8 & 24.2 & 21.7 \\
\hline No of households participating & 2970 & 3754 & 3838 \\
\hline$\%$ of households participating & 87.8 & 83.7 & 74.3 \\
\hline \multicolumn{4}{|c|}{ Nonfarm wage income } \\
\hline Shares in total income (\%) & 50.6 & 47.6 & 49.7 \\
\hline No of households participating & 323 & 661 & 991 \\
\hline$\%$ of households participating & 9.6 & 14.7 & 19.2 \\
\hline \multicolumn{4}{|c|}{ Nonfarm self employment income } \\
\hline Shares in total income (\%) & 23.6 & 28.2 & 28.6 \\
\hline No of households participating & 598 & 798 & 1172 \\
\hline$\%$ of households participating & 17.7 & 17.8 & 22.7 \\
\hline
\end{tabular}

Source: own calculations from Nigerian Living Standards Survey.

\section{Composition of household income by gender of the household head}

Male-headed households generated $28.1 \%$ of their income from farm activities; $49.7 \%$ and $27.6 \%$ from non-farm wage- and self-employment activities (Table 4). While female-headed households generated $22.2 \%$ of their income from farm activities; $44.3 \%$ and $28.1 \%$ from non-farm wage- and self-employment activities respectively. The participation in farm and nonfarm wage-employment activities was slightly higher 

minants of rural non-farm income diversification in Nigeria. J. Agribus. Rural Dev., 3(57), 279-288. http://dx.doi.org/10.17306/J. JARD.2020.01344

Table 4. Composition of household income by gender of the household head

\begin{tabular}{|c|c|c|}
\hline & Male & Female \\
\hline \multicolumn{3}{|c|}{ Farm income } \\
\hline Shares in total income (\%) & 28.1 & 22.2 \\
\hline No of households participating & 8251 & 2311 \\
\hline$\%$ of households participating & 81.1 & 18.9 \\
\hline \multicolumn{3}{|c|}{ Nonfarm wage income } \\
\hline Shares in total income (\%) & 49.7 & 44.3 \\
\hline No of households participating & 1739 & 236 \\
\hline$\%$ of households participating & 17.1 & 8.3 \\
\hline \multicolumn{3}{|c|}{ Nonfarm self employment income } \\
\hline Shares in total income $(\%)$ & 27.6 & 28.1 \\
\hline No of households participating & 1950 & 618 \\
\hline$\%$ of households participating & 19.2 & 21.6 \\
\hline
\end{tabular}

Source: own calculations from Nigerian Living Standards Survey.

for male-headed households, whereas it was the other way round for non-farm self-employment activities. $21.6 \%$ of the female-headed households were engaged in non-farm self-employment activities while $19.2 \%$ of the male-headed households were engaged in the same activities.

\section{Determinants of non-farm wage-employment income}

Empirical results presented in Table 5 show that the following variables are found to have a statistically significant positive influence on non-farm wage-employment income: value of assets, age, gender, and education level of the household head. These variables increase the nonfarm wage-employment income share. This implies, for instance, that the share of income from non-farm wage employment tends to rise with the age and level of education of the head of household. In other words, accumulated experience contributes to skills needed for non-farm wage employment. The highest returns of education are gained in non-farm wage employment. More specifically, an additional level of education increases the non-farm wage-employment income by $10.9 \%$. According to Minot et al. (2006), education facilitates access to a number of different income-earning activities, including wage-earning jobs. A positive and significant role of education in non-farm income diversification, especially non-farm wage employment, has been emphasised in most of the studies on income diversification and this report is in line with these previous studies (Minot et al., 2006; Schwarze, 2004; Malek and Koichi, 2009; Karttunen, 2009; Babatunde, 2008). Furthermore, the positive and significant influence of gender of the household head on non-farm wage-employment income share shows that male-headed households' earning income from wage-employment activities was $6.2 \%$ points higher than in the case of female-headed households. The reason for it could be the fact that men are able to seek for paid employment even beyond their immediate localities, while women are constrained due to domestic and childcare responsibilities.

Findings presented in Table 5 also show that household-size variable had a negative and significant influence on non-farm wage-employment income share, implying that households with larger number of persons had a reduced wage-employment income share by $0.6 \%$. This result confirms the findings of Ibekwe et al. (2010) who reported that a large household size negatively influences rural households' participation in non-farm activities. Similarly, the negative and significant regional variable of north-east implies that residing in the northeast region reduces the non-farm wage-employment income share by $10 \%$. The reason for it could be the security crisis in the north-east region of the country which reduces opportunities for wage-employment activities, especially in the rural areas of the region.

\section{Determinants of non-farm self-employment income}

The results of the estimates of the determinants of nonfarm self-employment income in Table 5 show that livestock, value of assets, age of the household head, gender of the household head and the regional variables had a significant and positive influence on the non-farm selfemployment income. This implies that an increase in these variables would lead to an increase in the non-farm self-employment income by some percentage points. For instance, an increase in the heads of livestock owned by the household would increase the non-farm self-employment income by $1.9 \%$. Similarly, an increase in the value assets owned by the households would increase the non-farm self-employment income by $69.1 \%$ points. This variable, according to Babatunde and Qaim (2009) facilitates the establishment of self-employed business. 

minants of rural non-farm income diversification in Nigeria. J. Agribus. Rural Dev., 3(57), 279-288. http://dx.doi.org/10.17306/J. JARD.2020.01344

Also, the non-farm self-employment income of maleheaded households was $4.7 \%$ points higher than in the case of their female counterparts. The share of non-farm income also tends to increase with the age of the household head. All the regional variables had a positive and significant influence on non-farm self-employment income share. This implies that households in the entire region earn income from one type of non-farm self-employment activity or another, but the share of income of households located in the south-west and north-central regions is higher than those located in other regions of the country. This may imply that opportunities for non-farm self-employment activities are better in those two regions in comparison to other regions.

The non-farm self-employment income is also negatively associated with education of the household head. The reason for it may be the fact that the non-farm selfemployment enterprises where households usually participate are mostly informal in nature and education is not so important.

\section{Determinants of overall income diversity}

As shown in Table 5, the value of assets, access to credit, south-west, north-east and north-central regional

Table 5. Tobit estimates of the determinants of income diversification

\begin{tabular}{|c|c|c|c|c|c|c|}
\hline \multirow{2}{*}{ Variables } & \multicolumn{2}{|c|}{$\begin{array}{c}\text { Nonfarm wage employment income } \\
\text { share }\end{array}$} & \multicolumn{2}{|c|}{$\begin{array}{l}\text { Nonfarm self employment income } \\
\text { share }\end{array}$} & \multicolumn{2}{|c|}{ Simpson diversification index } \\
\hline & coefficient & t-value & coefficient & t-value & coefficient & t-value \\
\hline Farmsize & -0.004 & -0.74 & -0.016 & $-2.64 *$ & -0.001 & -0.13 \\
\hline Livestock & $(\ldots)$ & $(\ldots)$ & 0.019 & $4.99 * * *$ & -0.008 & $-3.03 * *$ \\
\hline Assets & 5.790 & $1.68 *$ & 6.910 & $2.19 * *$ & 3.331 & $2.17 * *$ \\
\hline Hhsize & -0.006 & $-3.02 * *$ & -0.013 & $-6.86 * * *$ & -0.001 & -0.64 \\
\hline Age & 0.006 & $2.85^{* *}$ & 0.007 & $4.60 * * *$ & -0.003 & $-2.45 * *$ \\
\hline Sex & 0.062 & $3.06^{* *}$ & 0.047 & $3.04 * *$ & -0.015 & -1.26 \\
\hline Educ & 0.109 & $3.25 * *$ & -0.102 & $-2.21 * *$ & -0.034 & -1.13 \\
\hline Temploy & 0.005 & 0.83 & 0.003 & 0.51 & 0.008 & 1.49 \\
\hline Deptratio & -0.001 & -1.08 & 0.004 & 0.07 & 0.002 & 0.33 \\
\hline Illness & 0.023 & 1.34 & 0.019 & 1.10 & 0.002 & 0.01 \\
\hline Socialcap & -0.012 & -1.47 & -0.008 & -0.99 & -0.001 & -0.2 \\
\hline Credit & $(\ldots)$ & $(\ldots)$ & 0.005 & 0.37 & 0.044 & $2.93 * *$ \\
\hline Distance t_wk & 0.002 & 0.86 & -0.005 & -0.73 & -0.005 & -1.38 \\
\hline Migrant & -0.004 & -0.27 & -0.007 & -0.47 & -0.001 & -0.08 \\
\hline Southeast & -0.044 & -1.64 & 0.067 & $2.94 * *$ & 0.006 & 0.37 \\
\hline Southsouth & -0.001 & -0.07 & 0.204 & $8.65 * * *$ & -0.038 & $-2.12 * *$ \\
\hline Southwest & - & - & 0.242 & $8.43 * * *$ & 0.141 & $5.97 * * *$ \\
\hline Northeast & -0.101 & $-3.52 * * *$ & - & - & 0.092 & $5.04 * * *$ \\
\hline Northcentral & 0.002 & 0.08 & 0.212 & $8.33 * * *$ & - & - \\
\hline Northwest & -0.141 & $-4.77 * * *$ & -0.042 & $-2.10^{* *}$ & 0.102 & $5.93 * * *$ \\
\hline Constant & 0.768 & $11.47 * * *$ & 0.399 & $5.67 * * *$ & 0.122 & $2.27 * *$ \\
\hline Log likelihood & \multicolumn{2}{|c|}{-309.522} & \multicolumn{2}{|c|}{-542.127} & \multicolumn{2}{|c|}{-8505.859} \\
\hline LR Chi & \multicolumn{2}{|c|}{215.33} & \multicolumn{2}{|c|}{609.89} & \multicolumn{2}{|c|}{238.32} \\
\hline $\mathrm{P}>\mathrm{chi}^{2}$ & \multicolumn{2}{|c|}{0.0000} & \multicolumn{2}{|c|}{0.0000} & \multicolumn{2}{|r|}{0.0000} \\
\hline No of observations & \multicolumn{2}{|c|}{1975} & \multicolumn{2}{|c|}{2568} & \multicolumn{2}{|c|}{13033} \\
\hline
\end{tabular}

$* * *$ Indicates significance at the $1 \%$ level, $* *$ at the $5 \%$ level, and $*$ at the $10 \%$ level. Variables indicated by $(\ldots)$ are not considered. Source: authors computations from Nigerian Living Standards Survey. 
variables are significantly and positively related to the overall income diversity. For instance, an increase in a household's access to credit would open the door to a number of different economic activities. The results also revealed that the higher the value of households' assets, the more income households are likely to earn from diversifying into various economic activities.

Contrary to expectations, the variables of household size, total number of workers, dependency ratio, social capital and migrant status did not show any significant influence in any of the three models presented in Table 5. Babatunde and Quaim (2009), in their study also found that household size did not show any significant effect on income diversification in Kwara State, Nigeria. This according to them contradicts the popular notion that shrinking land availability and a surplus rural labour force are the main driving forces for income diversification in rural Africa.

\section{CONCLUSIONS AND RECOMMENDATIONS}

The study investigated the composition and determinants of rural non-farm income diversification in $\mathrm{Ni}$ geria. The study found that farming is the predominant occupation among rural households in the studied area. The study also found that although farming is the main occupation for most households, the majority of households in the studied area had fairly diversified sources of income and farming alone cannot sustain a sufficient livelihood of the rural households. Given that income from non-farm sources accounts for a higher share in household income, non-farm activities can no longer be considered as residual in terms of households in rural Nigeria. While farming remains the dominant income source for the poorest, non-farm occupations, and especially wage-employment activities, are the main income sources for the relatively richer households. Richer households also tend to be more diversified which was shown by using different measures of income diversification.

These patterns suggest that income diversification is not only a risk management strategy in rural Nigeria, as risks are generally more severe in case of the poorer households, nor does diversification seem to be primarily a response to the shrinking farmland availability, it rather appears that many households see diversification as a means to increase their overall income (Minot et al., 2006). The Tobit econometric model showed that education and value of assets are the key determinants of participation in non-farm activities. These factors improve the opportunities to start own business and find employment in more financially rewarding non-farm sectors. This shows that resource-poor households in rural areas are faced with considerable barriers to enter into remunerative non-farm activities. The evidence presented here also suggests that even relatively small gains in educational outcomes may considerably improve employment prospects in the non-farm sectors. Hence education is an important advantage to alleviate poverty if non-farm activities are to compensate for asset advantages.

The study recommends that any policy targeting poverty reduction in the studied area should focus on providing a favourable environment for rural households to engage in rural non-farm activities. It could include improving access to education and social capital assets. Given that non-farm incomes have been established to be an important component of rural economy in the studied area, careful consideration should be given to it in national accounting records.

Finally, given the significant influence of gender and credit on non-farm income diversification, policy measures to improve the participation of women in non-farm activities, especially self-employment activities, should be given consideration. Such measures could include skill-based training and entrepreneurial empowerment that will improve their livelihoods. Policies supporting rural households in obtaining formal credit, with low interest rates, which are directly targeted towards non-farm activities should also be implemented. This is because credit enables households to change their stock in physical capital within a short time to take advantage of income opportunities outside agriculture.

\section{SOURCE OF FINANCING}

Self financed by the authors.

\section{ACKNOWLEDGEMNT}

The authors acknowledge the Nigerian Bureau of Statistics, for releasing the data used for the analysis. 
Olugbire, O. O., Obafunsho, O. E., Olarewaju, T. O., Kolade, R. I., Odediran, F. A., Orumwense, L. A. (2020). The composition and determinants of rural non-farm income diversification in Nigeria. J. Agribus. Rural Dev., 3(57), 279-288. http://dx.doi.org/10.17306/J. JARD.2020.01344

\section{REFERENCES}

Anderson, D., Leiserson, M. (1980). Rural Non-farm Employment in Developing Countries. Econ. Dev. Cult. Chan., 28(2), 227-248.

Awoyemi, T.T. (2004). "Rural Households Diversification into Secondary Economic Activities: Options for Poverty Alleviation in Oyo State, Nigeria". Issues in African Rural Development Monograph Series. Monograph 34, ARPAN, Winrock International.

Babatunde, R.O. (2008). Income Portfolios in Rural Nigeria: Composition and Determinants. Trends Agric. Econ., 1(1), 35-41. Retrieved from: https://scialert.net/ abstract/?doi=tae.2008.35.41

Babatunde, O. (2009). Rural Non-farm Income and Inequality in Nigeria. IFPRI Discussion Paper 00899, International Food Policy Research Institute, Washington, U.S.A. Retrieved from: http://ebrary.ifpri.org/cdm/ref/collection/ p15738coll2/id/28321

Babatunde, R.O., Qaim, M. (2009). Patterns of Income Diversification in Rural Nigeria: Determinants and Impacts. Quart. J. Int. Agric., 28(4), 305-320.

Byerlee, D., De Janvry, A., Sadoulet, E. (2010). Agriculture for Development: Toward a New Paradigm. Ann. Rev. Res. Econ., 1(1), 1-20. DOI: 10.1146/annurev. resource.050708.144239

Davis, B., Giuseppe, S.D., Zezza, A. (2017). Are African households (not) leaving agriculture? Patterns of households' income sources in rural Sub-Saharan Africa. Food Policy, 67, 153-174. DOI: 10.1016/j.foodpol.2016.09.018

De Janvry, A., Sadoulet, E. (2000). Rural Poverty in Latin America: Determinants and Exit Paths. Food Policy, 25(4), 389-409. DOI: 10.1016/S0306-9192(00)00023-3

De Janvry, A., Sadoulet, E., Zhu, N. (2005). The Role Nonfarm Incomes in Reducing Rural Poverty and Inequality in China. Policy Res. Work. Paper. The World Bank.

Estruch, E., Grandelis, I. (2013). Promoting economic diversification and decent rural employment towards greater resilience to food price volatility. Discussion Paper. Rome, Italy: Food and Agriculture Organization. Retrieved May $6^{\text {th }} 2020$ from: http://www.fao.org/fileadmin/user_upload/ fao_ilo/pdf/Papers/DRE_Food_Price_Volatility.pdf

FAO (Food and Agriculture Organization) (2017). The State of Food and Agriculture: Leveraging Food Systems for Inclusive Rural Transformation. Rome: FAO Publication.

Gordon, A., Craig, C. (2004). Rural Non-Farm Activities and Poverty Alleviation in Sub-Saharan Africa. Policy Series 14. Chatham, United Kingdom: Natural Resources Institute.
Ibekwe, U.C., Eze, C.C., Ohajianya, D.O., Orebiyi, J.S., Onyemauwa, C.S., Korie, O.C. (2010). Determinants of Non Farm Income among Farm Households in South East Nigeria. Researcher, 2(7), 49-52.

Iliya, M.A. (1999). Income Diversification in the Semi-arid Zone of Nigeria: a study of Gigane, Sokoto North-WestNigeria. De-Agrarianisation and Rural Employment Network. Working Paper 39. Leiden: African Studies Center. Retrieved from: http://hdl.handle.net/1887/415

Karttunen, K. (2009). Rural Income Generation and Diversification - A Case Study in Eastern Zambia. Agric. Policy, No. 47. University of Helsinki Department of Economics and Management.

Lanjouw, P. (1998). Ecuador's Rural Nonfarm Sector as a Route Out of Poverty. Policy Research Working Paper No. 1094. Washington, D.C.: Development Research Group, World Bank.

Maddala, G.S. (1987). Econometrics. McGraw-Hill Book Company, USA.

Malek, M., Koichi, U. (2009). Determinants of Non-farm Income Diversification in Developed Villages of Bangladesh. Am. J. Econ. Bus. Admin., 1(2), 41-149.

Minot, N., Epprecht, M.T., Trung, Q.L. (2006). Income Diversification and Poverty in the Northern Uplands of Vietnam. Research Report No. 145. Washington, D.C.: International Food Policy Research Institute.

NBS (Nigerian Bureau of Statistics). (2004). Poverty Profile for Nigeria. Abuja, Nigeria: NBS.

NBS (Nigerian Bureau of Statistics). (2010). National Poverty Rates for Nigeria, 2003-2004 and 2009-2010. Abuja, Nigeria: NBS.

NISER (2004). "Understanding Poverty in Nigeria: NISER Review of Nigerian Development, 2001/2002". Ibadan, Nigeria: Nigerian Institute of Social and Economic Research.

Odoh, N.E., Nwibo, S.U., Eze, A.V., Igberi, C.O. (2019). Farm and Non-Farm Income Diversification Activities among Rural Households in Southeast, Nigeria. J. Agric. Ext., 23 (2), 113-121. Retrieved from http://aesonnigeria. org/ajm/index.php/jae/article/view/1688

Olowa, O.W. (2012). Concept, Measurement and Causes of Poverty: Nigeria in Perspective. Am. J. Econ., 2(1), 2536. DOI:10.5923/j.economics.20120201.04

Pham, T.H. (2007). Is Nonfarm Diversification a Way out of Poverty for Rural Households? Evidence from Vietnam in 1993-2004". A paper presented at the $6^{\text {th }}$ PEP Research Network General Meeting, Lima, Peru. DOI: 10.2139/ ssrn. 1715603

Reardon, T., Berdegúe, J., Escobar, G. (2001). Rural Nonfarm Employment and Incomes in Latin America: Overview and Policy Implications. World Dev., 29(3), 395-409. 
Olugbire, O. O., Obafunsho, O. E., Olarewaju, T. O., Kolade, R. I., Odediran, F. A., Orumwense, L. A. (2020). The composition and determinants of rural non-farm income diversification in Nigeria. J. Agribus. Rural Dev., 3(57), 279-288. http://dx.doi.org/10.17306/J. JARD.2020.01344

Schwarze, S. (2004). Determinants of Income Generating Activities of Rural Households: A quantitative study in the vicinity of Love-Lindu National Park in Central Sulawesi, Indonesia”. Goettingen: Institute of Rural Development, University of Goettingen.

Williams, E. (2016). Alternatives Approaches to Reducing Poverty and Inequality: Existing Evidence and Evidence Needs. Proceedings of PPIW Evidence Workshop. Retrieved from http://ppiw.org.uk/files/2016/11/Alternativeapproaches-to-poverty-reduction.pdf
World Bank (1990). World Development Report 1990: Poverty. Washington, D.C.: World Bank.

World Bank (1999). World Development Indicators 1999. Washington, D.C.: World Bank.

World Bank (2001). World Development Report 2000/2001: Attacking Poverty. Washington, D.C.: World Bank.

World Bank (2018). Poverty and Shared Prosperity 2018: Piecing Together the Poverty Puzzle. Washington, D.C.: World Bank.

World Bank (2020). Poverty and Equity Brief Nigeria Sub-Saharan Africa April 2020. Washington, D.C.: World Bank. 